\title{
Perbedaan Hardiness pada Wanita Menikah yang Berkarir dan Wanita Menikah yang Tidak Berkarir
}

\author{
Lydia Indira* dan Tania Gunawan \\ Fakultas Psikologi Universitas Jayabaya \\ * Corresponding author: lydia.indira2016@gmail.com
}

\begin{abstract}
Marriage and career has been an issue for women these days. For some women, career is something can not be done along with marriage life that they prefer to be a fulltime mom and housewife. The multiple roles seem become a burden for some women. But in contrast, some women seem to be fine with the multiple role that they can do the multiple roles altogether at the same time. This research aims to prove the hardiness difference between employed married women and unemployed married women. Hardiness in this research as a predicting factor of the difference between employed and unemployed married women on taking the multiple roles.84 employed married women and 93 unempl oyed married women were selected by random insidental sampling. Subjects aged 25-40 years, minimum bachelor degree and had at least one child. The hardiness scale was used to collect data. The result showed that there is a difference between employed and unemployed married women. Employed married women score higher on Hardiness than unemployed maried women.
\end{abstract}

\begin{abstract}
Abstrak
Rumah tangga dan karier nampaknya menjadi suatu permasalahan bagi wanita di masa kini. Untuk beberapa wanita, karier merupakan sesuatu yang tidak dapat dilakukan bersama dengan kehidupan berumah tangga sehingga mereka lebih memilih menjadi fulltime mom dan ibu rumah tangga saja. Peran ganda menjadi beban untuk sebagian wanita. Namun di sisi lain, ada wanita yang mampu melakukan kedua peran sekaligus di waktu yang bersamaan. Penelitian ini bertujuan untuk membuktikan perbedaan hardiness antara wanita menikah yang berkarier dan wanita menikah yang tidak berkarier. Hardiness dalam penelitian ini dijadikan sebagai faktor prediksi untuk menjawab pertanyaan mengapa ada wanita menikah yang mau berkarier dan ada wanita menikah yang enggan berkarier. 84 wanita menikah yang berkarier dan 93 wanita menikah yang tidak berkarier dipilih secara acak dan insidental dengan beberapa karakteristik yang harus dipenuhi. Karakteristik tersebut antara lain subjek penelitian harus berusia 25-40 tahun, pendidikan minimal S1, dan memiliki anak paling tidak satu. Hasil penelitian ini menunjukkan ada perbedaan hardiness antara wanita menikah yang berkarier dan wanita menikah yang tidak berkarier.
\end{abstract}

Keywords: Hardiness, Women, Career 


\section{PENDAHULUAN}

Sudah menjadi pandangan umum di masyarakat bahwa peran wanita sesudah menikah adalah menjadi seorang istri dan juga ibu. Mengurus, mendidik, dan membesarkan anak juga mengerjakan segala pekerjaan rumah tangga adalah tugas wanita. Hal ini adalah kodrat wanita yang tidak dapat dihindari. Seiring berkembangnya zaman, pandangan ini mulai ditinggalkan. Emansipasi atau kesetaraan gender telah merubah konsep peran wanita yang sebelumnya lekat dengan pekerjaan rumah tangga menjadi lebih luas. Dewasa ini, sering kita jumpai wanita yang sudah menikah tidak hanya bekerja di rumah mengurus anak dan segala pekerjaan rumah tangga, namun juga meniti karier dan membantu perekonomian keluarga.

Dalam Kamus Besar Bahasa Indonesia, wanita berarti perempuan dewasa. Sedangkan karier berarti wanita yang berkecimpung dalam kegiatan profesi. Wanita karier adalah wanita yang berkecimpung dalam kegiatan profesi seperti bidang usaha, perkantoran dan sebagainya. Berperan ganda sebagai istri, ibu dan wanita karier tentunya bukan hal yang mudah. Wanita menikah yang berkarier dituntut untuk bekerja secara profesional dan bisa membagi waktu antara keluarga dan pekerjaannya dengan baik. Tidak jarang mereka juga dituntut untuk memprioritaskan pekerjaan mereka daripada keluarga. Menurut Greenhause dan Beutell (1985), konflik peran terjadi ketika muncul tekanan atau ketidakseimbangan peran antara peran di pekerjaan dengan peran di dalam keluarga.

Wanita yang terlalu fokus pada pekerjaan di kantor, waktunya akan terbagi dan perannya di rumah akan berkurang. Suami akan kehilangan sosok istri dan anak juga akan kehilangan sosok ibu karena ditinggal bekerja. Sebaliknya, jika wanita karier lebih memilih keluarga dibanding pekerjaan, maka mereka akan dinilai tidak profesional. Dalam hal ini, mereka akan merasakan dilema ketika diminta untuk memilih memprioritaskan keluarga atau pekerjaan. Meskipun banyaknya tuntutan peran yang harus dilakukan dinilai dapat menambah beban pekerjaan, nyatanya cukup banyak wanita yang menjalankan peran-peran tersebut. Dengan berperan ganda, maka persoalan yang dihadapipun menjadi bertambah banyak dan beragam, oleh karena itu dibutuhkan ketangguhan untuk menghadapi semua persoalan yang dihadapi. Wanita yang memiliki ketangguhan melihat semua permasalahan itu sebagai suatu tantangan yang membantu mereka berkembang dan mengubahnya menjadi sesuatu yang menguntungkan.

Seseorang yang memiliki kepribadian yang tangguh mempunyai kecenderungan untuk mempersepsikan atau memandang peristiwa-peristiwa hidup yang potensial mendatangkan tekanan sebagai sesuatu yang tidak terlalu mengancam. Ini merupakan konsep yang digagas oleh Kobasa yang dinamakan sebagai Hardiness. Kobasa mendefinisikan Hardiness sebagai suatu karakteristik kepribadian individu yang kuat, tahan, dan stabil dalam menghadapi tekanan dan efek negatif pada suatu situasi. Kobasa menyatakan bahwa seseorang yang memiliki kepribadian Hardiness cenderung dapat mempersepsikan suatu situasi yang berpotensi mendatangkan stres menjadi situasi yang memberikan efek positif. Menurut Maddi (2013) Hardiness didasari oleh motivasi dan sikap berani untuk mengahadapi situasi yang sulit dan kemampuan untuk mengubah keadaan tertekan menjadi peluang individu untuk tumbuh. Kobasa (1982) menyebutkan bahwa ada tiga karakteristik hardiness, yaitu commitment, challenge, dan control atau sering disebut juga dengan 3C. 3C merupakan aspek yang saling berhubungan dan aspek-aspek ini akan terefleksi jika individu berhadapan dengan kejadian-kejadian yang membuat stress. 
Kobasa (1979) mengemukakan bahwa terdapat tiga aspek yang menjadi dasar pembentuk kepribadian tahan banting (hardiness). Aspek-aspek tersebut adalah:

1. Control, merupakan sikap individu yang secara positif dapat mempengaruhi dan mengendalikan perubahan situasi yang terjadi di sekitar. Aspek kontrol merupakan salah satu bentuk kemampuan individu dalam pengambilan keputusan. Orang dengan kemampuan kontrol yang tinggi tidak akan membiarkan dirinya berada dalam kepasifan ketika menghadapi situasi yang menekan tetapi mereka akan melakukan sesuatu sebagai solusi dan penyelesaian dalam menghadapi stresnya.

2. Commitment, menggambarkan sejauh mana individu terlibat pada suatu situasi yang sedang ia kerjakan. Individu yang berkomitmen melimpahkan seluruh kemampuannya untuk mencapai tujuan dan tidak mudah menyerah ketika dihadapkan dengan situasi yang menekan (Kreitner \& Kinicki, 2014). Individu yang mengerjakan suatu tugas dengan komitmen tinggi akan memberikan arti dalam setiap peristiwa yang ada di sekitarnya. Ia akan melibatkan diri dalam setiap kejadian dan bukan menghindarinya.

3. Challenge, mengacu pada perubahan yang dapat menjadi sebuah peluang individu untuk tumbuh. Individu dengan kepribadian tahan banting (hardiness) merefleksikan suatu perubahan sebagai bagian dari kehidupan yang normal, tidak ada satupun individu yang dapat terbebas dari perubahan. Individu dengan kepribadian tahan banting (hardiness) akan lebih fleksibel dan dapat beradaptasi dengan perubahan kehidupan.

Azar (2006) melakukan penelitian di Iran bahwa wanita menikah yang berkarier secara signifikan memiliki hardiness yang lebih tinggi daripada wanita menikah yang tidak berkarier. Beberapa wanita menganggap bahwa menjalankan peran ganda ini adalah suatu tantangan yang dapat membuat mereka berubah menjadi pribadi yang lebih baik, dan beberapa wanita lain menganggap peran ganda ini adalah stressor yang membebani mereka. Adapun kekurangan dari penelitian ini adalah hasil penelitian memperlihatkan tidak adanya perbedaan yang signifikan antara wanita menikah yang berkarier non-profesional dengan wanita menikah yang tidak berkarier. Serta kekurangan yang menurut peneliti penting adalah penelitian tersebut tidak melihat perbedaan hardiness pada wanita menikah yang tidak berkarier dari sisi pengalaman bekerja.

Adanya kepribadian tangguh atau hardiness tampaknya memberikan reaksi yang berbeda pada wanita menikah yang berkarier dengan yang tidak. Ada yang mampu menjalakan peran ganda sebagai istri, ibu sekaligus wanita karier dan ada juga yang tidak. Wanita menikah dengan hardiness yang tinggi mampu menjalani peran sebagai istri, ibu sekaligus wanita karier dengan baik, karena wanita yang memiliki hardiness melihat hal ini sebagai suatu tantangan yang dapat membuat mereka menjadi lebih baik. Selain itu, hardiness juga membuat mereka lebih kuat, tahan dan optimis dalam menghadapi masalah.

Berdasarkan definisinya, Kobasa mengkategorikan hardiness sebagai suatu kepribadian. Horney mengatakan bahwa salah satu faktor yang membentuk kepribadian adalah budaya (Feist \& Feist, 2013). Perbedaan kebudayaan di Iran dengan di Indonesia tentu ikut berperan dalam membentuk kepribadian hardiness pada wanita. Untuk itu peneliti merasa perlu melakukan penelitian ulang untuk melihat apakah ada perbedaan hardiness pada wanita menikah yang berkarier dan yang tidak berkarier di Indonesia, lebih spesifiknya peneliti melakukan penelitian di kota Bandung. Selain itu, peneliti ingin mengetahui perbedaan hardiness antara wanita menikah yang tidak berkarier dari sisi pengalaman kerjanya. 
Dari uraian di atas, ingin diketahui apakah ada perbedaan yang empirik antara hardiness pada wanita menikah yang berkarier dengan hardiness pada wanita menikah yang tidak berkarier.

\section{METODE PENELITIAN}

\section{Rancangan Penelitian}

Rancangan penelitian ini menggunakan pendekatan kuantitatif deskriptif yang bersifat uji beda atau metode komparatif. Sedangkan pengumpulan data menggunakan skala untuk menggali data mengenai Hardiness pada wanita menikah yang berkarir dan wanita menikah yang tidak berkarir. Pengukuran disusun dan divalidasi melalui uji validitas dan reliabilitas. Uji validitas dan reliabilitas dilaksanakan dengan uji terpakai, artinya diuji secara parallel dengan pelaksanaan penelitian korelasional, item yang tidak valid tidak dihitung dalam penelitian.

\section{Identifikasi Variabel Penelitian \\ Variabel Tunggal : Hardiness}

\section{Definisi Operasional Variabel Penelitian}

\section{Hardiness}

Hardiness adalah kepribadian pada wanita menikah yang cenderung mempersepsikan atau memandang peran ganda sebagai ibu dan wanita karier sebagai sesuatu yang tidak terlalu mengancam, yang dapat diukur melalui tiga aspek yaitu control, challenge, dan commitment.

\section{Populasi dan Sampel Penelitian}

\section{Populasi}

Populasi yang akan digunakan dalam penelitian ini Wanita menikah yang berkarir dan Wanita menikah yang tidak berkarir. Di Bandung.

\section{Karakteristik Sampel}

Pemilihan sampel dilakukan dengan metode classified random sampling, dimana setiap sampel dipilih secara acak sesuai dengan kriteria yang sudah ditentukan. Adapun karakteristik sampel adalah sebagai berikut:

- Wanita

- Sudah menikah

- Berusia 25 - 40 tahun

- Memiliki anak minimal satu orang.

\section{Subjek Penelitian}

Subyek dalam penelitian ini adalah 93 wanita menikah yang tidak berkarier, terdiri dari 31 responden yang tidak pernah bekerja sama sekali, 28 responden membuka usaha sampingan seperti membuka warung atau online shop, serta 34 responden pernah bekerja. Selain itu 84 subyek adalah 
wanita menikah yang berkarier, terdiri dari 32 responden yang memiliki profesi sebagai pekerja profesional (Dokter dan Guru) dan 52 responden yang memiliki profesi sebagai karyawan perusahaan.

\section{Pengujian Alat Ukur}

\section{Uji Validitas Skala Hardiness}

Perhitungan uji validitas koefisien korelasi (r) item dilakukan dengan bantuan SPSS 20.0 menggunakan koefisien korelasi Product-Moment Pearson. Skala Hardiness dalam bentuk kuesioner ini disebarkan kepada sampel yang berjumlah 177 orang, 93 orang dari kelompok wanita menikah yang tidak berkarir dan 84 orang dari kelompok wanita menikah yang berkarir. Kaidah perhitungan validitas item mengacu pada $r$ tabel dimana batas nilai $r$ hitung yang dipakai dengan taraf signifikan $(\alpha)$ sebesar $0,05(5 \%)$ dan banyaknya subjek penelitian sejumlah 177 orang $(\mathrm{N}=177)$. Apabila nilai $\mathrm{r}$ hitung $>\mathrm{r}$ table artinya item tersebut dinyatakan valid dan apabila $\mathrm{r}$ hitung $<\mathrm{r}$ table berarti item tersebut dinyatakan tidak valid. Dari tabel di atas, setelah uji validitas dengan menggunakan rumus Product Moment Pearson, maka diperoleh 37 item valid dengan batas nilai $r$ hitung $>0,1240$ dengan $\mathrm{N}=100$. 3 item sisanya masuk dalam kategori tidak valid atau gugur dengan batas nilai $r$ hitung 0,1240 .

\section{Uji Reliabilitas Skala Hardiness}

Untuk menguji reliabilitas alat ukur dilakukan dengan menggunakan teknik pengukuran alpha crombach, dengan bantuan program SPSS 20.0. Dari hasil pengujian diperoleh reliabilitas $(\alpha)$ untuk skala Hardiness adalah sebesar 0,887 dari 37 item. Hasil pengujian tersebut menunjukan koefisien yang reliabel dan sudah konsisten untuk dilakukan ke tahap penelitian. 


\section{Analisis Data}

Metode analisis data dalam penelitian ini didasarkan atas tujuan hipotesis penelitian, yaitu untuk mengetahui perbedaan hardiness pada wanita menikah yang berkarier dan yang tidak berkarier. Penelitian ini dianalisis menggunakan uji statistik parametric, yakni uji Independent Samples T-Test untuk menguji perbedaan rata - rata dari kedua kelompok sampel, serta uji analisis varian satu jalan (One Way ANOVA) untuk menguji perbedaan sub-kelompok sampel. Kedua uji statistik parametris ini dilakukan dengan bantuan program komputer SPSS 20.0.

Dalam melakukan uji beda , ada beberapa asumsi yang harus dipenuhi yaitu:

a. Distribusi data harus normal

b. Varians harus homogen.

Uji Normalitas Data pada penelitian ini menggunakan bantuan SPSS 20.0 dengan Uji Normalitas Kolmogorov Smirnov. Hasil uji Normalitas diperoleh p-value sebesar 0,173. Nilai tersebut lebih besar dari 0,05 sehingga dapat disimpulkan bahwa data yang diuji berdistribusi normal.

Uji Homogenitas dilakukan dengan tujuan untuk mengetahui apakah varians kedua sample sudah homogen atau dapat diasumsikan sama. Uji Homogenitas diperlukan sebagai prasyarat dari penggunaan Independent Sample T-Test. Uji Homogenitas pada penelitian ini dilakukan dengan bantuan program SPSS 20.0 dengan menggunakan uji Levene. Berdasarkan hasil output SPSS diketahui bahwa nilai signifikansi kelompok wanita menikah yang berkarier dengan kelompok wanita menikah tidak berkarier sebesar $0,045<0,05$. Artinya kedua kelompok data memiliki varians yang tidak sama atau tidak homogen. Tahap selanjutnya adalah melakukan uji Independent Sample T-Test dan uji One Way ANOVA. 
HASIL DAN PEMBAHASAN

Hasil Analisis Uji Beda

Independent Samples Test

\begin{tabular}{|c|c|c|c|c|c|c|c|c|c|c|}
\hline & & \multicolumn{2}{|c|}{$\begin{array}{l}\text { Levene's Test } \\
\text { for Equality of } \\
\text { Variances }\end{array}$} & \multicolumn{7}{|c|}{ t-test for Equality of Means } \\
\hline & & \multirow[t]{2}{*}{$F$} & \multirow[t]{2}{*}{ Sig. } & \multirow[t]{2}{*}{$\mathrm{T}$} & \multirow[t]{2}{*}{ Df } & \multirow[t]{2}{*}{$\begin{array}{l}\text { Sig. } \\
(2- \\
\text { tailed })\end{array}$} & \multirow[t]{2}{*}{$\begin{array}{c}\text { Mean } \\
\text { Differe } \\
\text { nce }\end{array}$} & \multirow[t]{2}{*}{$\begin{array}{c}\text { Std. } \\
\text { Error } \\
\text { Differe } \\
\text { nce }\end{array}$} & \multicolumn{2}{|c|}{$\begin{array}{c}95 \% \\
\text { Confidence } \\
\text { Interval of the } \\
\text { Difference } \\
\end{array}$} \\
\hline & & & & & & & & & Lower & Upper \\
\hline $\begin{array}{l}\text { Skor } \\
\text { Total }\end{array}$ & $\begin{array}{l}\text { Equal } \\
\text { variances } \\
\text { assumed } \\
\text { Equal } \\
\text { variances } \\
\text { not assumed }\end{array}$ & 4,069 & ,045 & $\begin{array}{r}16,5 \\
22 \\
\\
16,2 \\
89\end{array}$ & $\begin{array}{r}175 \\
156 \\
014\end{array}$ & ,000 & 18,435 & 1,116 & 16,233 & 20,638 \\
\hline
\end{tabular}

\begin{tabular}{|ll|r|r|}
\hline & & $\begin{array}{r}\text { Authoritarian } \\
\text { Parenting }(X)\end{array}$ & $\begin{array}{c}\text { Impostor } \\
\text { Syndrome }(Y)\end{array}$ \\
\hline Authoritarian Parenting $(X)$ & Pearson Correlation & 1 & $.230^{*}$ \\
& Sig. (2-tailed) & & .021 \\
& $\mathrm{~N}$ & 100 & 100 \\
\hline Impostor Syndrome $(\mathrm{N})$ & Pearson Correlation & $.230^{*}$ & 1 \\
& Sig. (2-tailed) & .021 & \\
& $\mathrm{~N}$ & 100 & 100 \\
\hline
\end{tabular}

${ }^{*}$. Correlation is significant at the 0.05 level (2-tailed).

Berdasarkan perhitungan yang dilakukan dengan menggunakan rumus uji beda dua sampel (Independent sample $t$-test) dengan bantuan program komputer SPSS 20.0, dapat dilihat bahwa nilai $p$-value atau nilai sig. ( 2 - tailed) pada penelitian ini sebesar 0,000. Nilai tersebut lebih kecil daripada taraf nyata penelitian yaitu 0,05 (5\%). Karena nilai signifikansi lebih kecil dari 0,05, maka Ho ditolak dan Ha diterima. Artinya terdapat perbedaan hardiness pada wanita menikah yang berkarier dan wanita menikah yang tidak berkarier. 


\section{Hasil Analisis One Way Anova}

\section{ANOVA}

Skor Total

\begin{tabular}{|l|r|r|r|r|r|}
\hline & Sum of Squares & Df & Mean Square & F & Sig. \\
\hline Between Groups & 19267,166 & 4 & 4816,791 & 155,802 &, 000 \\
Within Groups & 5317,557 & 172 & 30,916 & & \\
Total & 24584,723 & 176 & & & \\
\hline
\end{tabular}

Berdasarkan perhitungan yang dilakukan dengan menggunakan rumus analisis varians satu jalur (One Way ANOVA) dengan bantuan program komputer SPSS 20.0, dapat dilihat bahwa nilai $p$-value atau nilai sig. pada penelitian ini sebesar 0,000 . Nilai tersebeut lebih kecil daripada taraf nyata penelitian yaitu $0,05(5 \%)$. Karena nilai signifikansi lebih kecil dari 0,05 , artinya terdapat perbedaan hardiness pada sub-kelompok wanita menikah yang berkarier dan sub-kelompok wanita menikah yang tidak berkarier.

\section{Pembahasan}

\begin{tabular}{|ll|r|r|r|r|}
\hline & Kelompok & \multicolumn{1}{c|}{ G } & Mean & Std. Deviation & Std. Error Mean \\
\hline Skor & Wanita Karier & 83 & 130,08 & 8,266 &, 907 \\
Total & $\begin{array}{l}\text { Wanita Tidak } \\
\text { Berkarier }\end{array}$ & 94 & 111,65 & 6,559 &, 677 \\
\hline
\end{tabular}

Berdasarkan table diatas, Wanita menikah yang berkarier memiliki skor rata-rata hardiness yang lebih tinggi sebesar 130,08 dibandingkan dengan rata-rata hardiness wanita yang tidak berkarier sebesar 111,65.

Gambaran ini menunjukan bahwa secara keseluruhan, wanita menikah yang berkarier memiliki hardiness yang lebih tinggi dibandingkan dengan wanita menikah yang tidak berkarier. Hasil penelitian ini sejalan dengan penelitian yang dilakukan oleh Azar (2006), hal ini disebabkan karena pekerjaan dengan memperoleh upah, meningkatkan hardiness (Azar, 2006).

Maddi (2013) mengatakan bahwa hardiness adalah suatu karakteristik yang dipelajari melalui pembiasaan, bukan diwariskan secara genetik. Terbiasa dalam menghadapi tekanan baik dalam kehidupan rumah tangga maupun dalam kehidupan berkarier membuat wanita menikah yang berkarier memiliki hardiness yang lebih tinggi. Tekanan yang didapatkan bukan saja repotnya mengelola rumah tangga, juga adanya tuntutan peran sebagai isteri dan ibu. Selain itu tuntutan peran sebagai professional maupun sebagai karyawan memiliki tekanan tersendiri. 
Individu dengan kepribadian hardiness yang tinggi mempercayai bahwa mereka dapat mengontrol setiap peristiwa yang penuh tekanan dan menafsirkannya menjadi peristiwa yang positif dan konstruktif serta menguraikannya menjadi tantangan yang memungkinkan untuk dijadikan sebagai pelajaran (Hystad, 2012), hal ini dapat dibuktikan dengan data penelitian ini. Skor rata - rata dimensi control wanita menikah yang berkarier lebih tinggi daripada wanita menikah yang tidak berkarier. Wanita menikah yang berkarier mampu menilai dan berpikir positif terhadap peristiwa yang penuh tekanan, hal ini disebabkan karena wanita menikah yang berkarier telah terbiasa menghadapi tekanan baik di rumah ataupun di kantor. Misalnya wanita menikah yang berkarier selain harus mengurus pekerjaan rumah tangga seperti memasak, mendidik anak, mengurus suami atau memikirkan biaya pendidikan anak juga harus memikirkan permasalahan di kantor misalnya deadline, pekerjaan yang menumpuk atau lembur. Tekanan tersebut membuat wanita menikah yang berkarier terbiasa, sehingga mereka akan lebih tangguh atau hardy dalam menghadapi tekanan.

Challenge atau tantangan menurut Kobasa (1982) adalah keyakinan bahwa perubahan, dibandingkan dengan stabilitas, merupakan suatu hal normatif dalam hidup. Individu yang memiliki challenge yang tinggi dapat berpikir terbuka, fleksibel, serta memiliki toleransi yang tinggi (Maddi, 2013). Individu dengan tantangan suka mencari pengalaman baru dan menarik (Kobasa, 1982). Dalam penelitian ini, wanita menikah yang berkarier memiliki skor suka mencari pengalaman baru serta memiliki pikiran terbuka dan fleksibel yang lebih tinggi secara signifikan daripada wanita menikah yang tidak berkarier. Hal ini dapat disebabkan karena peran yang diambil oleh wanita menikah yang berkarier lebih banyak daripada wanita menikah yang tidak berkarier. Semakin banyak peran yang diambil, semakin luas cakrawala dan fleksibilitas pemikiran seorang individu. Fleksibilitas dalam berpikir dan pemikiran yang terbuka akan mempengaruhi individu ketika mengambil keputusan. Individu dengan pemikiran yang terbuka akan menanggapi peristiwa penuh tekanan sebagai tantangan, bukan sebagai masalah, sehingga individu tersebut akan lebih siap ketika menghadapi tekanan.

Komitmen merupakan kecenderungan seseorang untuk terlibat secara mendalam dengan aktivitas-aktivitas dalam hidup, termasuk di dalamnya keluarga, pekerjaan, hubungan interpersonal, dan institusi sosial (Kobasa, 1982). Commitment wanita menikah yang berkarier lebih tinggi daripada wanita menikah yang tidak berkarier. Hal ini menunjukkan bahwa wanita menikah yang berkarier memiliki keinginan untuk terlibat dengan situasi hidupnya lebih tinggi daripada wanita menikah yang tidak berkarier. Salah satu indikator commitment adalah mampu mengatasi stres. Wanita menikah yang berkarier mampu mengatasi stres lebih baik daripada wanita menikah yang tidak berkarier, hal ini dapat disebabkan karena mereka terbiasa dalam menghadapi peristiwa penuh tekanan.

\section{KESIMPULAN}

Berdasarkan hasil penelitian, terdapat perbedaan Hardiness yang signifikan pada wanita menikah yang berkarier dan wanita menikah yang tidak berkarier. Berdasarkan temuan yang 
diperoleh dalam penelitian ini, terdapat saran agar mencari sampel dari profesi yang lebih beragam dan membandingkan Hardiness berdasarkan profesi yang ditekuni.

\section{UCAPAN TERIMAKASIH}

Penelitian ini dapat dilaksanakan berkat dukungan dari wanita yang bekerja maupun ibu rumah tangga di Bandung yang telah menyediakan waktu di sela-sela kesibukannya untuk mengisi kuesioner. Dukungan juga dberikan oleh beberapa rekan yang bersedia membantu dalam penyebaran kuesioner ini . Semoga semua dukungan dan bantuan tersebut mendapatkan Rahmat Allah SWT. Aamiin.

\section{DAFTAR PUSTAKA}

Azar, I.A. (2006). Hardiness : A Comparative Study of Emloyed and Unemployed Married Woman ini Iran. http://ijps.tums.ac.ir/.

Azwar, S.(2010). Metode Penelitian; Yogyakarta. Balai Pustaka

Denmark, F.L \& Paludi, M.A (2008). Psychology of Women: A Handbook of Issues \& Theories. London : Praeger

Dodik, A.A \& Kamsih (2012). Hubungan antara Kepribadian Hardiness dengan Stres Kerja pada Anggota Polri Bagian Operasional di Polresta Yogyakarta. Jurnal Insight vol 10. No 1. 37-38 .

Feist, J \& Feist, G (2010). Teori Kepribadian. Jakarta. Salemba Humanika.

Feldman, R.S (2013). Pengantar Psikologi; Understanding Psychology. Edisi 10. Jakarta. Salemba Humanika.

Greenhaus,J. \& Beutell, N.J (1985) : Source of Conflict between Work and Family Roles : The Academy of Management Review. Vol 10, No 176 -78.

Hystad, S. (2012) ; Exploring Gender Equivalence and Bias in a Measure of Psychology Hardiness. International Journal of Psychology Studies. Vol 4. No 4. Norway.

Kardum, I (2012). The Structure of Hardiness, Its Measurement Invariance Across Gender \& Relationships with Personality Traits \& Mental Health Ooutcomes. http://hrcak.sree.hr/

Kreitner, R \& Kinicki, A. (2014). Perilaku Organisasi Edisi 9. Jakarta. Salemba Empat.

Kobasa, S.C (1979) Stressful Life Events, Personality and Health : An Inquiry into Hardiness. Journal of Personality and Social Psychology Vol 37, 1-10.

Kobasa, S.C. (1982). Hardiness and Health : A Perspective Study. Journal of Personality and Social Psychology Vol 42, 168-177. 
Maddi, S.R (2012). The Story of Hardiness: Twenty years of Theorizing, Reaserch \& Practice. Consulting Psychology Journal. Practice and Research vol. 54 No 3, 175-185.

Maddi, S.R (2013). Hardiness Turning Stressful Circumstances into Resilient Growth. Springer.

Sugiono. (2014). Metode penelitian pendidikan pendekatan kuantitatif, kualitatif, dan research and development. Bandung: Alfabeta.

DOI : https://doi.org/10.31479/intensi.v1i1.5 